\title{
Increasing the Durability and Freeze-Thaw Strength of Concrete Paving Stones Produced from Ahlat Stone Powder and Marble Powder by Special Curing Method
}

\author{
Abdulrezzak Bakis iD \\ Bitlis Eren University, Faculty of Engineering and Architecture, Department of Civil Engineering, Bitlis, Turkey \\ Correspondence should be addressed to Abdulrezzak Bakis; arezzakbakis@gmail.com
}

Received 27 June 2019; Revised 7 October 2019; Accepted 24 October 2019; Published 11 November 2019

Guest Editor: Roozbeh Rezakhani

Copyright ( 2019 Abdulrezzak Bakis. This is an open access article distributed under the Creative Commons Attribution License, which permits unrestricted use, distribution, and reproduction in any medium, provided the original work is properly cited.

\begin{abstract}
This study highlights an investigation of using construction waste materials, i.e., Ahlat stone powder and marble powder, in fabricating interlocked paving stones. In this study, the durability and freeze-thaw strength of concrete paving stones produced from Ahlat stone powder and marble powder were increased by the special curing method. Six different types of paving stones were fabricated for study and were subjected to two different curing regimes. Tests of water absorption, splitting tensile strength, surface abrasion, and freeze-thaw were carried out for the specimens. In 3 days and at $20 \pm 5^{\circ} \mathrm{C}$ of water curing, the splitting tensile strength was $3.7 \mathrm{MPa}$, the surface abrasion value was $9.8 \mathrm{~cm}^{3} / 50 \mathrm{~cm}^{2}$, and the freeze-thaw value was $0.39 \mathrm{~kg} / \mathrm{m}^{2}$ for those interlocked paving stones produced from Ahlat stone powder. After special combined curing, these improved to $3.9 \mathrm{MPa}, 17.2 \mathrm{~cm}^{3} / 50 \mathrm{~cm}^{2}$, and $0.63 \mathrm{~kg} /$ $\mathrm{m}^{2}$, respectively. Accordingly, for interlocked paving stones produced from marble powder, in 3 days and at $20 \pm 5^{\circ} \mathrm{C}$ water curing, the splitting tensile strength, surface abrasion, and freeze-thaw were $3.9 \mathrm{MPa}, 7.9 \mathrm{~cm}^{3} / 50 \mathrm{~cm}^{2}$, and $0.34 \mathrm{~kg} / \mathrm{m}^{2}$, respectively. After special combined curing, these values improved to $4.1 \mathrm{MPa}, 14.8 \mathrm{~cm}^{3} / 50 \mathrm{~cm}^{2}$, and $0.57 \mathrm{~kg} / \mathrm{m}^{2}$, respectively. The findings of this study validate increase in durability and freeze-thaw strength of concrete paving stones with special curing.
\end{abstract}

\section{Introduction}

Concrete paving stones, which are widely used in urban roads, pavement, and recreation areas [1], are fabricated by mixing cement, aggregate, water, and additives in certain ratios [2]. The history of parquet road applications could be traced back to as early as the age of the Roman Empire [3]. Currently, interlocked concrete paving stones have been popularized in European and American countries [4]. Concrete paving stones are produced in different grades, such as square cobblestones, tombstones, and interlocked paving stones, the third one being the most common [5].

Interlocked paving stones offer many advantages, compared with concrete and asphalt pavements. First, the need for maintenance and repair is less. Second, the material is economical as only domestic materials are consumed during production. Third, the speed of production and the material capacities are higher. Fourth, they are readily accessible for traffic immediately after being laid on the road. Fifth, a damaged surface can be repaired in a short time by provision of a new paving stone, thus preventing the occurrences of unwanted patch defects on the coating surfaces. Sixth, they can be produced in different colors and shapes, hence, the variability and design flexibility. In contrast, there are a few disadvantages in using these materials. First, although the manufacturing process is easy, the application phase to the road surface is time-consuming and necessitates high-quality workmanship [6]. Second, concrete pavements may weaken over time due to corrosion, erosion, shrinkage, fatigue cracking, or the like [7]. Third, concrete pavements are believed to increase heat waves globally [8].

The most common materials employed in the fabrication of interlocked pavement stones are crushed limestone aggregates. Relatively, this study investigates the use of alternative production materials, namely, waste materials, such as Ahlat stone powder and marble powder. 
Ahlat stone is a solid waste that contributes to environmental pollution and waste landfills. Originally known as ignimbrites, Ahlat stone is widely used in Bitlis Province of the Ahlat region and is one of the pyroclastic rocks that contain abundant pumice and volcanic glass due to the explosion of Nimrod crater. Waste Ahlat stone powder is generated in a significant amount after stone cutting in the Ahlat stone quarries. Nevertheless, the presence of pores in the material body gives the extremely low compressive and bending strength, and therefore, such materials cannot be used as aggregates in concrete production. On this basis, Ahlat stone has limited applicability in the construction sector [9] and is rather used mainly as a wall stone in structures. However, the strength of Ahlat stone concrete pavement can be reinforced by mixing Ahlat stone powder with concrete using a special mixing method. Hattatoglu and Bakis stated that Ahlat stone powder was used as ignimbrite powder for producing reactive powder concrete and found out that the maximum compressive and bending strengths of the concrete were $124.99 \mathrm{MPa}$ and $9.18 \mathrm{MPa}$, respectively [10]. Bostanci investigated the time-dependent weathering performance of various ignimbrites with varying color and textural properties collected from the Nevşehir region against physical and chemical influences. They also evaluated the effect of deterioration on the physical and mechanical properties of the ignimbrite specimens, as well as the capillary water absorption characteristics relative to durability performance [11]. The author of this paper realizes that no study has been carried out yet regarding the use of waste Ahlat stone powder in the production of interlocked paving stones. The Ahlat stone powder investigated herein is of the size range $0.15-0.60 \mathrm{~mm}$.

Besides Ahlat stone, marble is another solid waste that contributes to environmental pollution and forms waste fields $[12,13]$. A considerable amount of marble waste is formed upon removal of blocks as marble quarries are processed [14]. In this regard, there is an essential need for the conscientious evaluation of waste materials. Li et al. suggested an alternative technique called the paste replacement method, where marble dust is added as replacement to an equal volume of paste without necessarily changing the paste's mix proportions. Here, they produced a number of mortar mixes with different amounts of marble dust and added these as a replacement of either paste or cement to test the workability, compressive strength, and microstructure of the concrete material. Accordingly, they found that addition of marble dust as paste replacement has improved the strength and microstructure of the manufactured concrete [15]. Vardhan et al. investigated the strength, permeation, and microstructural properties of concrete incorporating waste marble as partial replacement of the fine aggregates and confirmed that waste marble has the potential as an alternate fine aggregate to improve the overall performance of the concrete, as well as for sustainable development [16]. Similarly, several studies investigated the use of marble waste as an additive to cementitious matrix building materials and confirmed that incorporation of marble waste significantly improved the mechanical properties and thermal insulation of concrete [17-19]. Using a special concrete mixing method for marble powder in concrete, the strength of marble concrete pavement can be increased. Some studies discussed the production of interlocked paving stones using marble aggregate and did not use marble powder in 100\% of the aggregates in the production of interlocked paving stones. In this study, marble powder, of the previously mentioned size range, is used in $100 \%$ ratio of the aggregates. Specifically, this paper investigates the usability of waste materials Ahlat stone powder and marble in the production of interlocked paving stones. Six different types of interlocked paving stones are produced, under two different types of curing applications. Two curing types, namely, standard water curing and combined curing, were applied for the interlocked paving stones. The literature did not specify any standard for the combined curing of hardened concrete. Therefore, a special combined curing type was applied for the interlocked paving stones.

Many experimental studies have been conducted on durability of concrete and mortar. Pathirage et al. investigated the effect of alkali silica reaction on the mechanical properties of aging mortar bars. Crushed limestone aggregates are used and mechanical properties of mortar at different curing temperatures are evaluated in their study [20].

Water absorption, splitting tensile strength, surface abrasion, and freeze-thaw tests of different types of interlocked paving stones were carried out, and the results were compared with reference-interlocked paving stone concrete under specification limits [21]. The results of this study indicated that waste materials, such as Ahlat stone powder and marble powder, can be potentially employed in the production of interlocked paving stones. The findings of this study validate increase in durability and freeze-thaw strength of concrete paving stones with special curing.

\section{Materials and Methods}

\subsection{Materials}

2.1.1. Binders (Cement and Silica Fume). The main material in the production of interlocked paving stones was CEM I 42.5 N Portland cement type, in accordance with TS EN 1971 standard [22]. The cement material was supplied by Limak Cement Industry and Trade Inc.

A silica fume named MasterRoc MS 610, supplied by BASF Chemistry Industry and Trade Inc., was used in accordance with ASTM C 618 and AASHTO M 307 standards $[23,24]$. The physical, chemical, and mechanical properties of the binders used in the production of the stones are shown in Table $1[25,26]$.

2.1.2. Superplasticizer. The material was supplied by BASF Chemistry Industry and Trade Inc. Its properties are listed in Table 2 [26].

A superplasticizer named MasterGlenium 128, which is based on polycarboxylic ether, was used in accordance with TS EN-934-2 + A1 standard [27].

2.1.3. Aggregates Used in Interlocked Paving Stones. Six different types of interlocked paving stones were manufactured for the purpose of this study, as depicted in Table 3. 
TABLE 1: Chemical, physical, and mechanical properties of binders.

\begin{tabular}{lcc}
\hline Properties & Cement & Silica fume \\
\hline $\mathrm{SiO}_{2}(\%)$ & 19.28 & 95.83 \\
$\mathrm{Fe}_{2} \mathrm{O}_{3}(\%)$ & 2.99 & 0.37 \\
$\mathrm{Al}_{2} \mathrm{O}_{3}(\%)$ & 5.09 & 0.76 \\
$\mathrm{Na}_{2} \mathrm{O}(\%)$ & 0.18 & - \\
$\mathrm{CaO}(\%)$ & 63.14 & 0.53 \\
$\mathrm{Cl}(\%)$ & 0.01 & - \\
$\mathrm{MgO}(\%)$ & 1.96 & 1.29 \\
$\mathrm{SO}_{3}(\%)$ & 2.81 & 0.63 \\
$\mathrm{~K}_{2} \mathrm{O}(\%)$ & 0.71 & - \\
$\mathrm{Ignition}$ loss $(\%)$ & 3.22 & 0.59 \\
$\mathrm{Compressive} \mathrm{strength} \mathrm{(28} \mathrm{days)}(\mathrm{MPa})$ & 52.20 & - \\
$\mathrm{Initial}$ set (min) & 153 & - \\
Final set (min) & 206 & - \\
Specific gravity $\left(\mathrm{g} / \mathrm{cm}^{3}\right)$ & 3.13 & 2.3 \\
Specific surface $\left(\mathrm{cm}^{2} / \mathrm{g}\right)$ & 3067 & $>150000$ \\
\hline
\end{tabular}

Table 2: Properties of superplasticizer.

\begin{tabular}{lc}
\hline Properties & Value \\
\hline Density & $1.1 \mathrm{~kg} /$ Liter \\
Form & Brown, liquid \\
Chloride quantity & $<0.1 \%$ \\
Alkaline quantity & $<3.0 \%$ \\
pH & 6 \\
\hline
\end{tabular}

TABLE 3: Interlocked paving stone type, code, aggregate type, and size.

\begin{tabular}{lccc}
\hline $\begin{array}{l}\text { Interlocked } \\
\text { paving stone type }\end{array}$ & $\begin{array}{c}\text { Interlocked } \\
\text { paving stone code }\end{array}$ & $\begin{array}{c}\text { Aggregate } \\
\text { type }\end{array}$ & $\begin{array}{c}\text { Aggregate } \\
\text { size }(\mathrm{mm})\end{array}$ \\
\hline RWC & $6-1$ & $\begin{array}{c}\text { Crushed } \\
\text { limestone } \\
\text { Crushed } \\
\text { RCC }\end{array}$ & $0-16$ \\
ASWC & $6-2$ & $0-16$ \\
ASCC & $2-1$ & $\begin{array}{c}\text { Ahlat stone } \\
\text { powder } \\
\text { Ahlat stone } \\
\text { powder } \\
\text { Marble }\end{array}$ & $0.15-0.60$ \\
MSWC & $2-2$ & $\begin{array}{c}\text { powder } \\
\text { Marble }\end{array}$ & $0.15-0.60$ \\
MSCC & $4-1$ & $0.15-0.60$ \\
\hline
\end{tabular}

In particular, RWC refers to the reference-interlocked paving stone produced from crushed limestone and obtained after 3 days at $20 \pm 5^{\circ} \mathrm{C}$ standard water curing; RCC was obtained by a curing application combined to that for RWC; ASWC was produced from only Ahlat stone powder without coarse aggregate and obtained after 3 days at $20 \pm 5^{\circ} \mathrm{C}$ standard water curing application; ASCC was obtained from a curing application combined to that for ASWC; MSWC was produced from only marble powder without coarse aggregate and obtained after 3 days at $20 \pm 5^{\circ} \mathrm{C}$ standard water curing; and MSCC was obtained from a curing application combined to that for MSWC. Table 3 defines that coarse aggregates were not used in the production of ASWC and ASCC interlocked paving stones; rather, only $0.15-0.6 \mathrm{~mm}$ Ahlat stone powder was used as the aggregate.

Likewise, coarse aggregates were not employed in MSWC and MSCC interlocked paving stones; rather only $0.15-0.6-\mathrm{mm}$ marble powder was used as the aggregate. Drinkable city water was for the production.

(1) Limestone Aggregate for the Production of RWC (Reference) and RCC Interlocked Paving Stones. Selected limestone aggregates were employed for the production and were supplied by Adabag Building Industry Incorporated Company. The chemical, physical, and mechanical properties of the aggregates are shown in Table 4 [28], whereas the actual images are depicted in Figure 1.

Note that the aggregates used in the production of the reference-interlocked paving stone (RWC) are crushed limestone within the size range of $0-16 \mathrm{~mm}$, as indicated in Table 3.

(2) Ahlat Stone Powder for the Production of ASWC and ASCC Interlocked Paving Stones. Figure 2 describes the appearance of Ahlat stone powder used in the production of ASWC and ASCC, which were retrieved from the Ahlat Ovakisla quarry.

Tables 5 and 6 provide a list of the chemical [29], physical, and mechanical properties of the Ahlat stone [29].

Table 6 describes the low unit weight of Ahlat stone, reflecting the stone's porous structure and, thereby, its low compressive and bending strengths.

(3) Marble Powder for the Production of MSWC and MSCC Interlocked Paving Stones. Figure 3 depicts the appearance of marble stone and marble powder used for the production of MSWC and MSCC. The marble powder was supplied by HMF Marble Industry.

The chemical, physical, and mechanical properties of marble are listed in Tables 7 [30, 31] and 8 [31], respectively.

In Table 8, note that marble has low porosity, indicating its low water absorption property and, thereby, the material's high compressive and bending strengths.

2.2. Method. Ahlat stone powder within the size range of $0.15-0.60 \mathrm{~mm}$ was the main component of the interlocked paving stones, whose production has been suggested by several studies through the use of marble aggregates. The literature did not mention the use of marble powder in $100 \%$ of the aggregates. Such is the context of this study, where marble powder of size $0.15-0.60 \mathrm{~mm}$ was incorporated in the production process. The usability of Ahlat stone powder and marble powder in the fabrication was validated in the fabricated six different types of interlocked paving stones, one of which was a reference concrete. Two curing applications were applied to the stones. Moreover, each stone type was subjected to water absorption, splitting tensile strength, surface abrasion, and freeze-thaw tests. Results of the tests for the new types were compared with the reference-interlocked paving stone 
TABle 4: Chemical, physical, and mechanical properties of the limestone aggregates.

\begin{tabular}{|c|c|}
\hline Properties & Value \\
\hline $\mathrm{SiO}_{2}(\%)$ & 0.16 \\
\hline $\mathrm{Fe}_{2} \mathrm{O}_{3}(\%)$ & 0.85 \\
\hline $\mathrm{Al}_{2} \mathrm{O}_{3}(\%)$ & 0.12 \\
\hline $\mathrm{CaO}(\%)$ & 54.58 \\
\hline $\mathrm{MgO}(\%)$ & 1.75 \\
\hline $\mathrm{K}_{2} \mathrm{O}(\%)$ & 0.09 \\
\hline $\mathrm{Na}_{2} \mathrm{O}(\%)$ & 0.04 \\
\hline $\mathrm{TiO}_{2}(\%)$ & 0.01 \\
\hline Ignition loss (\%) & 42.40 \\
\hline Specific gravity $\left(\mathrm{g} / \mathrm{cm}^{3}\right)$ & 2.77 \\
\hline Water absorption by weight (\%) & 1.38 \\
\hline Los Angeles abrasion (\%) & 26.17 \\
\hline
\end{tabular}

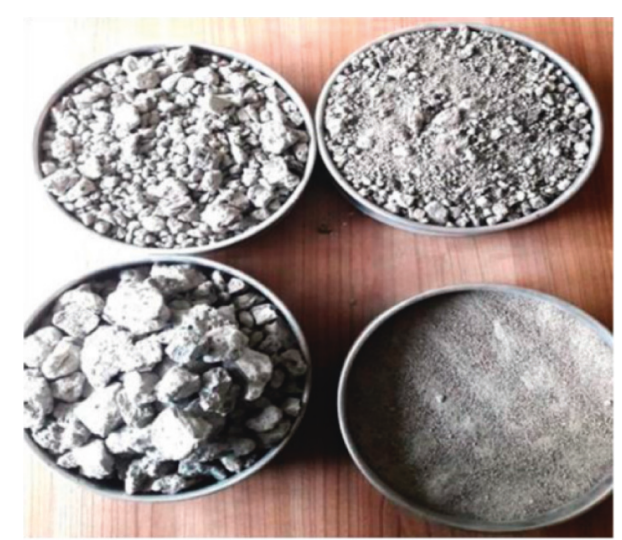

FIGURE 1: Limestone aggregates used for RWC production.

concretes and specification limits under the TS 2824 EN 1338 standard (concrete paving blocks-requirements and test methods) [21].

\subsubsection{Mixture Ratio of Interlocked Paving Stones}

(1) RWC and RCC Interlocked Paving Stones. As in Table 3, crushed limestone was the aggregate for RWC and RCC. A sieve analysis of the aggregates was carried out in accordance with TS EN 933-1 standard [32]. The results are shown in Table 9.

Note from Table 9 that the aggregates were designed with $30 \%$ of the crushed coarse limestone and $70 \%$ of the limestone powder. Figure 4 illustrates the gradation curves for the aggregates.

Standard TS 802 emphasizes that the gradation curve for such aggregates must lie between lines A16 and B16 or between lines B16 and C16 [33]. The concrete aggregate granulometry conforms to TS802, as depicted in Figure 4. The mixture ratio and amounts for the production of RWC and RCC interlocked paving stones are shown in Table 10.

Accordingly, note from Table 10 that the aggregates were designed with components of $70 \%$ crushed limestone sand and $30 \%$ coarse limestone. Note also that the water/binder ratio of the concrete mixture was 0.35 .
(2) New Type of Interlocked Paving Stones. Different theories of mixing have been applied to achieve a tight structure of the mixture forming materials $[33,34]$. Such theories were derived from Mooney's suspension viscosity model [34-36]. Table 11 shows the different mixture ratios for Mooney's model for a paving stone unit [37]. Here, the water/binder and silica fume/cement ratios were 0.12 and 0.25 , respectively. All samples taken had dimensions of $165 \times 200 \times 80 \mathrm{~mm}$.

As shown in Table 11, Portland cement and silica fume were considered together as binder for calculating the water/ binding ratio.

(3) ASWC and ASCC Interlocked Paving Stones. The mixing ratio and amounts established for ASWC and ASCC are listed in Table 12. The ratio between the total mixture weight and the amount of cement for one unit of the paving stone can be obtained using the following equation:

total concrete mixture weight $=2.806 \times$ cement weight.

Accordingly, $1 \mathrm{~m}^{3}$ of the concrete mixture weight corresponds to $2200 \mathrm{~kg}$. Using equation (1), the amount of cement in the mixture was calculated at $784 \mathrm{~kg}$. Thus, the amount of other materials used in the production of ASWC and ASCC was based on this calculated quantity, as depicted in Table 12.

In Table 12, note that the water/binder and silica fume/ cement ratios for the concrete mixture were 0.35 and 0.25 , respectively.

(4) MSWC and MSCC Interlocked Paving Stones. Similarly, the water/binder and silica fume/cement ratios of the concrete mixture for MSWC and MSCC were 0.35 and 0.25 , respectively. The mixing ratio and amounts are listed in Table 13.

Here, $1 \mathrm{~m}^{3}$ concrete mixture corresponds to a unit weight of $2200 \mathrm{~kg}$. Using equation (1), the amount of cement in the mixture was calculated at $784 \mathrm{~kg}$. Thus, the amount of other materials used in mixing ratios for MSWC and MSCC was based on this quantity, as depicted in Table 13. The water/binder ratio for both MSWC and MSCC was equal to that for RWC and RCC.

2.2.2. Curing Types. Two curing types, namely, standard water curing and combined curing, were applied for the interlocked paving stones. The literature did not specify any standard for the combined curing of hardened concrete. Hattatoglu and Bakis stated that the combined curing type with the highest compressive strength was obtained with consecutive water curing at $20^{\circ} \mathrm{C}$ for 7 days, hot water curing at $90^{\circ} \mathrm{C}$ for 2 days, and drying oven curing at $180^{\circ} \mathrm{C}$ for 2 days [10]. In the study, the test results of RWC, ASWC, and MSWC samples were determined after standard water curing at $20 \pm 5^{\circ} \mathrm{C}$ for 3 days, whereas the test results of RCC, ASCC, and MSCC samples were determined after combined curing at $20 \pm 5^{\circ} \mathrm{C}$ standard water curing for 3 days, and 

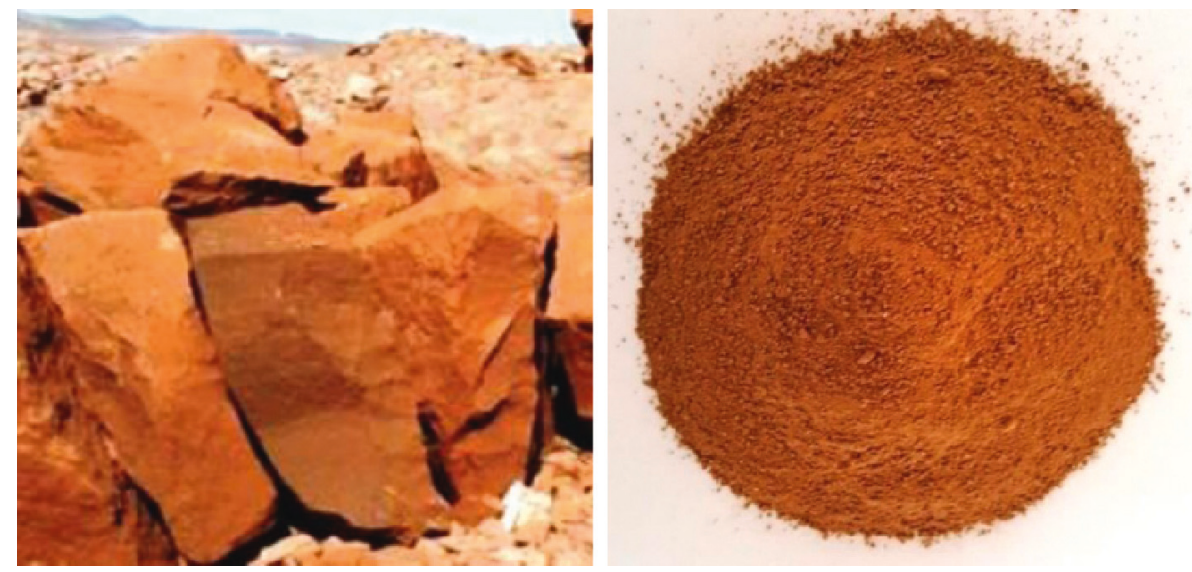

FIgURE 2: Ahlat stone powder used for ASWC and ASCC production.

TABLE 5: Chemical properties of Ahlat stone.

\begin{tabular}{lcccccccc}
\hline Component & $\mathrm{Na}_{2} \mathrm{O}$ & $\mathrm{MgO}$ & $\mathrm{Al}_{2} \mathrm{O}_{3}$ & $\mathrm{SiO}_{2}$ & $\mathrm{~K}_{2} \mathrm{O}$ & $\mathrm{CaO}$ & $\mathrm{TiO}_{2}$ & $\mathrm{Fe}_{2} \mathrm{O}_{3}$ \\
\hline Percentage & 5.51 & 0.24 & 16.01 & 64.11 & 4.78 & 1.64 & 0.44 & 4.91 \\
\hline
\end{tabular}

TABLE 6: Chemical and mechanical properties of Ahlat stone.

\begin{tabular}{lcccccc}
\hline $\begin{array}{l}\text { Specific gravity } \\
\left(\mathrm{g} / \mathrm{cm}^{3}\right)\end{array}$ & $\begin{array}{c}\text { Porosity } \\
(\%)\end{array}$ & $\begin{array}{c}\text { Water absorption by } \\
\text { weight }(\%)\end{array}$ & $\begin{array}{c}\text { Surface abrasion loss } \\
\left(\mathrm{cm}^{3} / 50 \mathrm{~cm}^{2}\right)\end{array}$ & $\begin{array}{c}\text { Unit weight } \\
\left(\mathrm{g} / \mathrm{cm}^{3}\right)\end{array}$ & $\begin{array}{c}\text { Compressive } \\
\text { strength }(\mathrm{MPa})\end{array}$ & $\begin{array}{c}\text { Bending strength } \\
(\mathrm{MPa})\end{array}$ \\
\hline 2.60 & 27.31 & 20 & 29 & 1.89 & 10.6 & 1.59 \\
\hline
\end{tabular}
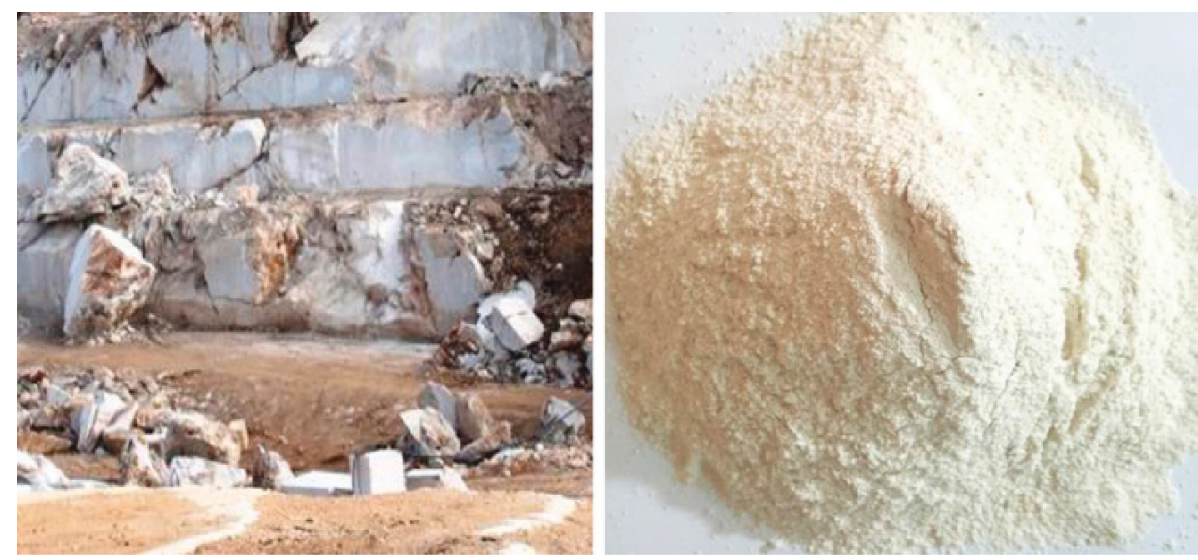

FIgURE 3: Marble powder used for MSWC and MSCC production.

TABLE 7: Chemical properties of marble.

\begin{tabular}{lcccccccccc}
\hline $\mathrm{Na}_{2} \mathrm{O}(\%)$ & $\mathrm{MgO}(\%)$ & $\mathrm{Al}_{2} \mathrm{O}_{3}(\%)$ & $\mathrm{SiO}_{2}(\%)$ & $\mathrm{K}_{2} \mathrm{O}(\%)$ & $\mathrm{CaO}(\%)$ & $\mathrm{TiO}_{2}(\%)$ & $\mathrm{Fe}_{2} \mathrm{O}_{3}(\%)$ & $\mathrm{P}_{2} \mathrm{O}_{5}(\%)$ & Ignition loss (\%) \\
\hline$<0.01$ & 1.41 & $<0.01$ & 0.14 & $<0.01$ & 55.72 & $<0.01$ & 0.11 & 0.01 & 42.6 \\
\hline
\end{tabular}

TABle 8: Physical and mechanical properties of marble.

\begin{tabular}{lcccccc}
\hline $\begin{array}{l}\text { Specific gravity } \\
\left(\mathrm{g} / \mathrm{cm}^{3}\right)\end{array}$ & $\begin{array}{c}\text { Porosity } \\
(\%)\end{array}$ & $\begin{array}{c}\text { Water absorption by } \\
\text { weight }(\%)\end{array}$ & $\begin{array}{c}\text { Surface abrasion loss } \\
\left(\mathrm{cm}^{3} / 50 \mathrm{~cm}^{2}\right)\end{array}$ & $\begin{array}{c}\text { Unit weight } \\
\left(\mathrm{g} / \mathrm{cm}^{3}\right)\end{array}$ & $\begin{array}{c}\text { Compressive } \\
\text { strength }(\mathrm{MPa})\end{array}$ & $\begin{array}{c}\text { Bending strength } \\
(\mathrm{MPa})\end{array}$ \\
\hline 2.73 & 0.2 & 0.1 & 33.3 & 2.71 & 64.8 & 6.5 \\
\hline
\end{tabular}


TABle 9: Sieve analysis for RWC and RCC.

\begin{tabular}{lcccc}
\hline Sieve size $(\mathrm{mm})$ & Weight remaining on sieve $(\mathrm{g})$ & Total weight remaining on sieve $(\mathrm{g})$ & Total weight remaining on sieve $(\%)$ & Passing $(\%)$ \\
\hline 16 & - & - & - & 16 \\
8 & 480 & 480 & 30 & 84 \\
4 & 420 & 900 & 45 & 70 \\
2 & 450 & 1350 & 58 & 71 \\
1 & 390 & 1740 & 85 & 29 \\
0.5 & 390 & 2130 & 86 & 14 \\
0.25 & 450 & 2580 & & \\
\hline
\end{tabular}

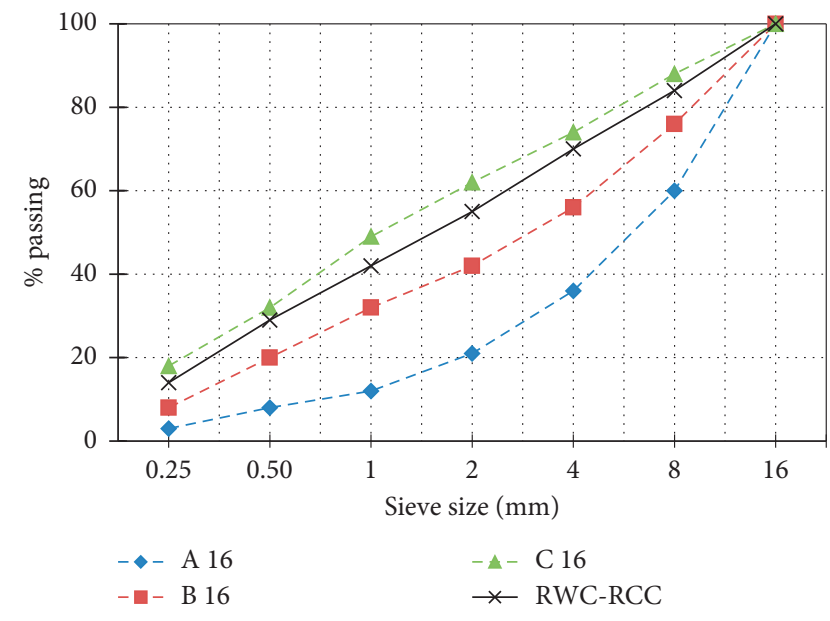

Figure 4: Gradation curve of aggregates for RWC and RCC.

TABLE 10: The mixture ratio and amounts of RWC and RCC interlocked paving stones.

\begin{tabular}{lcc}
\hline Material & Mixture ratio & $\begin{array}{c}\text { Quantity }(\mathrm{kg} / \\
\left.\mathrm{m}^{3}\right)\end{array}$ \\
\hline $\begin{array}{l}\text { Portland cement } \\
\text { Limestone aggregate }(0-4 \mathrm{~mm})\end{array}$ & 1.00 & 250 \\
Limestone aggregate & 5.21 & 1303 \\
$(4-16 \mathrm{~mm})$ & 2.24 & 559 \\
Water & 0.35 & 88 \\
Total & 8.8 & 2200 \\
\hline
\end{tabular}

TABLE 11: Concrete mixture ratios according to Richard and Cheyrezy [37].

\begin{tabular}{lc}
\hline Material & Mixture ratio \\
\hline Portland cement & 1.00 \\
Silica fume & 0.25 \\
Quartz sand $(0.15-0.60 \mathrm{~mm})$ & 1.10 \\
Superplasticizer & 0.016 \\
Water & 0.15 \\
Total & 2.516 \\
\hline
\end{tabular}

$200 \pm 5^{\circ} \mathrm{C}$ drying oven curing for 2 days. A description for each type of curing is provided in Table 14.

Accordingly, the specimen code for the interlocked paving stones, the type of aggregate in the concrete mixtures, and the types of curing are shown in Table 15.

From Table 15, the standard curing was for 3 days at $20 \pm 5^{\circ} \mathrm{C}$, whereas the combined curing involved 3 days at
TABLE 12: The mixture ratio and amounts for the production of ASWC and ASCC.

\begin{tabular}{lcc}
\hline Material & Mixture ratio & $\begin{array}{c}\text { Quantity } \\
\left(\mathrm{kg} / \mathrm{m}^{3}\right)\end{array}$ \\
\hline Portland cement & 1.00 & 784 \\
Silica fume & 0.25 & 196 \\
Ahlat stone powder $(0.15-0.60 \mathrm{~mm})$ & 1.10 & 862 \\
Superplasticizer & 0.016 & 13 \\
Water & 0.44 & 345 \\
Total & 2.806 & 2200 \\
\hline
\end{tabular}

TABLE 13: The mixture and amounts for the production of MSWC and MSCC.

\begin{tabular}{lcc}
\hline Material & Mixture ratio & Quantity $\left(\mathrm{kg} / \mathrm{m}^{3}\right)$ \\
\hline Portland cement & 1.00 & 784 \\
Silica fume & 0.25 & 196 \\
Marble powder $(0.15-0.60 \mathrm{~mm})$ & 1.10 & 862 \\
Superplasticizer & 0.016 & 13 \\
Water & 0.44 & 345 \\
Total & 2.806 & 2200 \\
\hline
\end{tabular}

TABLE 14: Two curing applications for the production of interlocked paving stones.

\begin{tabular}{lcc}
\hline $\begin{array}{l}\text { Curing } \\
\text { symbol }\end{array}$ & Curing description & Curing type \\
\hline WC & 3 days at $20 \pm 5^{\circ} \mathrm{C}$ water curing & $\begin{array}{c}\text { Standard water } \\
\text { curing }\end{array}$ \\
CC & $\begin{array}{c}3 \text { days at } 20 \pm 5^{\circ} \mathrm{C} \text { water curing }+2 \\
\text { days at } 200 \pm 5^{\circ} \mathrm{C} \text { drying oven curing }\end{array}$ & $\begin{array}{c}\text { Combined } \\
\text { curing }\end{array}$ \\
\hline
\end{tabular}

$20 \pm 5^{\circ} \mathrm{C}$ of the standard water curing, followed by 2 days at $200 \pm 5^{\circ} \mathrm{C}$ of drying oven curing.

2.2.3. Test Methods. The water absorption, splitting tensile strength, surface abrasion, and freeze-thaw tests for the interlocked paving stones were performed in accordance with TS 2824 EN 1338 standard [21]. This standard covers the materials, properties, requirements, and test methods of the cement-bound concrete pavement blocks without reinforcement used for floor covering. This standard specifies the use of concrete pavement blocks such as sidewalk pavement, bicycle lane pavement, parking lots pavement, and road pavement. 
TABLE 15: Code, aggregate type, and curing type for the interlocked paving stones.

\begin{tabular}{lccc}
\hline Interlocked paving stone type & Specimen code & Aggregate type in concrete mixture & Curing type \\
\hline RWC (reference) & $6-1$ & Crushed limestone $(0-16 \mathrm{~mm})$ & Standard water curing \\
RCC & $6-2$ & Crushed limestone $(0-16 \mathrm{~mm})$ & Combined curing \\
ASWC & $2-1$ & Ahlat stone powder $(0.15-0.60 \mathrm{~mm})$ & Standard water curing \\
ASCC & $2-2$ & Ahlat stone powder $(0.15-0.60 \mathrm{~mm})$ & Combined curing \\
MSWC & $4-1$ & Marble powder $(0.15-0.60 \mathrm{~mm})$ & Standard water curing \\
MSCC & $4-2$ & Marble powder $(0.15-0.60 \mathrm{~mm})$ & Combined curing \\
\hline
\end{tabular}

(1) Water Absorption Test Method. The water absorption test is performed to determine the water absorption percentage of the samples. The samples were left in the curing pool at $20 \pm 5^{\circ} \mathrm{C}$ for 3 days until constant weight was reached. The samples were then removed from the curing pool, dried, and weighed. This way, the initial weight $\left(M_{1}\right)$ of the test samples was found. The samples were then placed in the drying oven and dried for 3 days at $105 \pm 5^{\circ} \mathrm{C}$ until constant dry weight $\left(M_{2}\right)$ was reached. The water absorption $\left(W_{a}\right)$ of each sample was calculated in terms of weight percentage using the following equation:

$$
W_{a}=\frac{M_{1}-M_{2}}{M_{2}} \times 100 \text {. }
$$

In the calculation, three samples from each type of interlocked paving stones were taken, and the average of the three values was obtained. The curing process at $200^{\circ} \mathrm{C}$ changes the microstructure, i.e., the pore structures. After the curing process at $200^{\circ} \mathrm{C}$, the water absorption test was not made because this test for the interlocked paving stones was performed in accordance with TS 2824 EN 1338 standard. Nonstandard application was not performed.

(2) Splitting Tensile Strength Test Method. Splitting tensile strength tests for the interlocked paving stones were performed in accordance with TS 2824 EN 1338 standard [21]. The splitting tensile strength test is carried out to give information about the strength of the materials. A load was applied by increasing the tension per second $(0.05 \pm 0.01 \mathrm{MPa})$. The test results were calculated using the following equations [21]:

$$
\begin{aligned}
& S=L \times t, \\
& T=\frac{0.637 \times k \times P}{S}, \\
& k=1.3-30 \times\left(0.18-\frac{t}{1000}\right)^{2}, \\
& F=\frac{P}{L},
\end{aligned}
$$

where $S$ is the splitting area $\left(\mathrm{mm}^{2}\right), L$ is the splitting section length $(\mathrm{mm}), t$ is the interlocked paving stone thickness $(\mathrm{mm}), T$ is the splitting tensile strength $(\mathrm{MPa}), P$ is the splitting load (N), $k$ is the correction coefficient, and $F$ is the splitting load per unit area $(\mathrm{N} / \mathrm{mm})$.

As mentioned in the earlier sections, each interlocked paving stone had dimensions of $165 \times 200 \times 80 \mathrm{~mm}$. For each specimen, the calculated values for $L, t, S$, and $k$ were $200 \mathrm{~mm}$,
$80 \mathrm{~mm}, 16000 \mathrm{~mm}^{2}$, and 1.00 , respectively. Following the TS 2824 EN 1338 standard [21], eight samples were broken for each type of interlocked paving stones. The splitting tensile strength was calculated as the average of the values.

(3) Surface Abrasion Test Method. The abrasion test is carried out to measure the resistance of materials to surface abrasion. The Böhme abrasion test is designed to obtain abrasion loss. A total of 16 cycles, each with 22 subcycles, were applied to the samples. Abrasion loss $(\Delta V)$ at the end of the 16 cycles was calculated through the following equation [21]:

$$
\Delta V=\frac{\Delta m}{\rho r},
$$

where $\Delta V$ is the volume loss after 16 cycles $\left(\mathrm{cm}^{3}\right), \Delta m$ is the mass loss after 16 cycles (g), and $\rho r$ is the density of the sample $\left(\mathrm{g} / \mathrm{cm}^{3}\right)$.

Three samples from each type of interlocked paving stones were taken, and the abrasion loss was calculated as the average of all three values obtained.

(4) Freeze-Thaw Test Method. The freeze-thaw test is performed to measure durability of materials. Freeze-thaw tests for the interlocked paving stones were performed in accordance with TS 2824 EN 1338 standard [21]. Figure 5 displays temperature and time cycles for the freeze-thaw test according to the TS 2824 EN 1338 standard [21].

Limit values of temperature and time cycles for the freeze-thaw test are given in Table 16.

Each interlocked paving stone was cut to a dimension of $120 \times 80 \times 80 \mathrm{~mm}$. The surface area applied for the freezethaw test was $9600 \mathrm{~mm}^{2}$. The mass loss $(I)$ per unit area of the sample was calculated using the following equation [21]:

$$
I=\frac{M}{A},
$$

where $M$ is the total mass loss of material leaving the specimen after 28 days of cycles $(\mathrm{kg}), A$ is the surface area applied for freeze-thaw $\left(\mathrm{m}^{2}\right)$, and $I$ is the mass loss per unit area $\left(\mathrm{kg} / \mathrm{m}^{2}\right)$.

For the freeze-thaw value, three samples from each type of interlocked paving stones were taken, and the average of these three values was calculated.

\section{Results and Discussion}

3.1. Production of Interlocked Paving Stones. Figures 6(a)-6(d) are the illustrative photographs of the drying oven curing, and they show the appearance of the produced RWC (6-1) and 


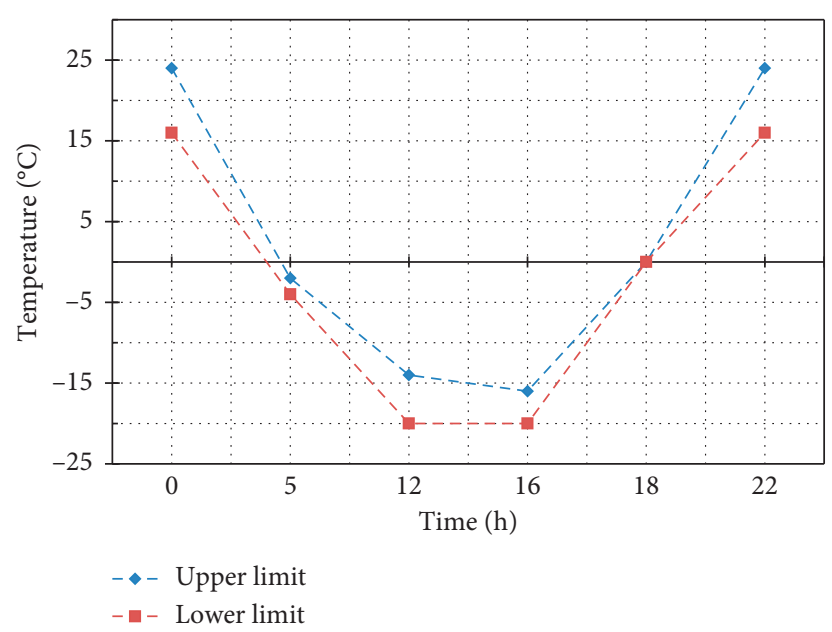

Figure 5: Temperature and time cycles for the freeze-thaw test.

TABLE 16: Limit values of temperature and time cycles for the freeze-thaw test [21].

\begin{tabular}{lccc}
\hline \multicolumn{2}{c}{ Upper limit } & \multicolumn{2}{c}{ Lower limit } \\
Time $(\mathrm{h})$ & Temperature $\left({ }^{\circ} \mathrm{C}\right)$ & Time $(\mathrm{h})$ & Temperature $\left({ }^{\circ} \mathrm{C}\right)$ \\
\hline 0 & 24 & 0 & 16 \\
5 & -2 & 3 & -4 \\
12 & -14 & 12 & -20 \\
16 & -16 & 16 & -20 \\
18 & 0 & 20 & 0 \\
22 & 24 & 24 & 16 \\
\hline
\end{tabular}

RCC (6-2), ASWC (2-1) and ASCC (2-2), and MSWC (4-1) and MSCC (4-2) interlocked paving stones, respectively.

3.2. Results of the Water Absorption Test. The results of the water absorption test for each type of the fabricated interlocked paving stones are shown in Table 17.

As indicated, the water absorption values of the new type of interlocked paving stones produced from Ahlat stone and marble powder were lower by approximately $5 \%$ and $20.34 \%$, respectively, than that of RWC. Figure 7 provides an illustrative graph for the results.

From Table 17 and Figure 7, a specification limit was defined by the water absorption by weight $\left(W_{a}\right)$ values of the interlocked paving stones. Accordingly, Figure 8 illustrates the unit volume weight for each paving stone.

TS 2824 EN 1338 [21] does not define a specification limit for the unit volume weight of the interlocked paving stones. Four of the new types of interlocked paving stones, namely, RCC, ASWC, ASCC, and MSCC, were lighter than RWC. In contrast, MSWC was heavier than RWC.

3.3. Results of the Splitting Tensile Strength Test. Figure 9 shows actual images of the broken specimens subjected to the splitting tensile strength test.

Accordingly, the results of the splitting tensile strength test are indicated in Table 18.

The splitting tensile strength of RWC increased by approximately $5 \%$, with the application of combined curing.
Similarly, the splitting tensile strength of all other interlocked paving stones with applied combined curing was higher by $5 \%$ than those applied with standard water curing. This was due to the application of high heat to the concrete paving stone by combined curing. Hydration of the cement was accelerated by combined curing. In this way, higher strength was obtained than the concrete paving stones. Figure 10 shows the results of the splitting tensile strength test.

From Table 18 and Figure 10, the values of splitting tensile strength and splitting load per unit area $(F)$ for the interlocked paving stones defined a specification limit. Specifically, the splitting tensile strength of all new interlocked paving stones was higher than that for RWC. Thus, ASWC, ASCC, MSWC, and MSCC proved more resistant than RWC by $2.78 \%, 8.33 \%, 8.33 \%$, and $13.9 \%$, respectively.

3.4. Results of the Böhme Abrasion Test. Figure 11 displays the abrasion test of RWC (6-1), RCC (6-2), ASWC (2-1), and MSWC (4-1), respectively.

Results of the Böhme abrasion test for all the interlocked paving stones are listed in Table 19.

From Table 19, the abrasion loss of RCC, ASWC, ASCC, MSWC, and MSCC was higher by approximately 9\%, 7\%, $87 \%, 14 \%$, and $61 \%$, respectively, than that of RWC. Figure 12 illustrates the results of the Böhme abrasion test for the interlocked paving stones.

Based on Table 19 and Figure 12, there was a defined specification limit for the values of abrasion loss for all specimens.

3.5. Results of the Freeze-Thaw Test. All abrasion values of the interlocked paving stones provide the specification limits, as shown in the results of the freeze-thaw test in Table 20.

The freeze-thaw mass loss of RCC, ASWC, ASCC, and MSCC was higher by approximately 37\%, 11\%, 80\%, and $63 \%$, respectively, than that of RWC. In contrast, the freeze-thaw mass loss of MSWC was lower by 


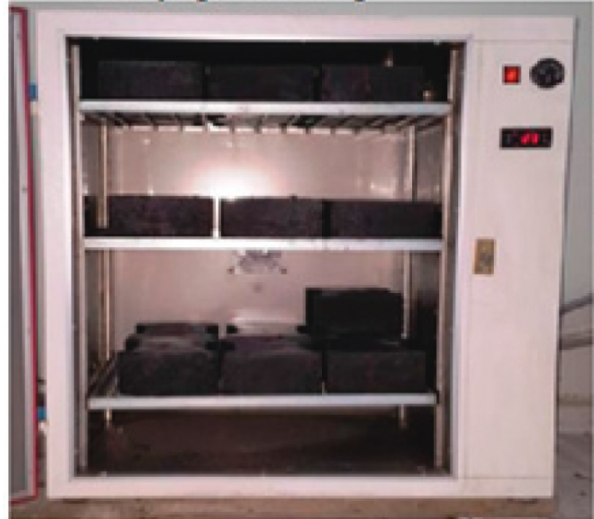

(a)

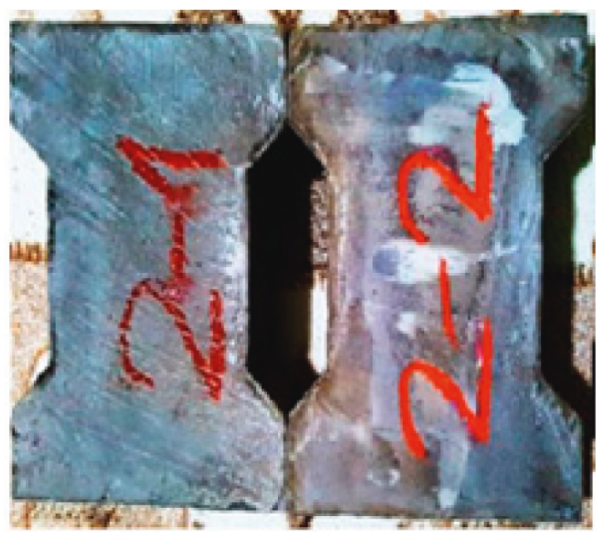

(c)

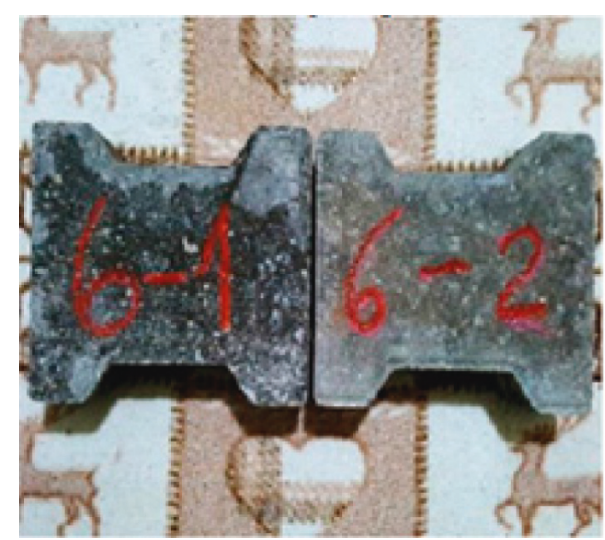

(b)

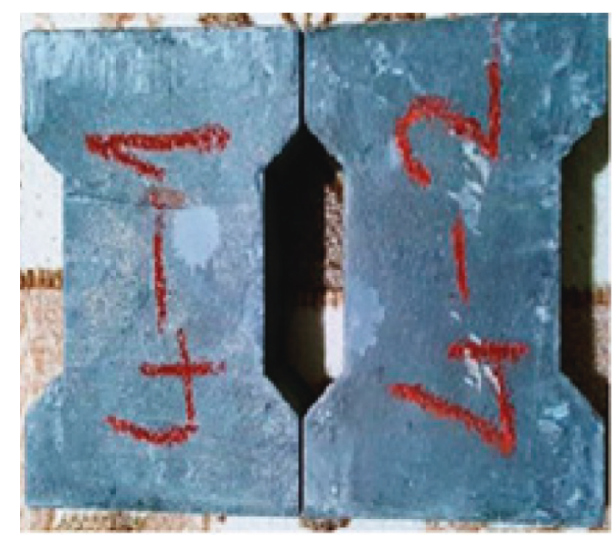

(d)

FIgURE 6: The appearance of the drying oven curing and interlocked paving stones. (a) The drying oven curing. (b) RWC and RCC paving stones. (c) RWC and RCC paving stones. (d) MSWC and MSCC paving stones.

TABLE 17: Results of the absorption test for the interlocked paving stones.

\begin{tabular}{|c|c|c|c|c|c|}
\hline $\begin{array}{l}\text { Interlocked paving } \\
\text { stone type }\end{array}$ & $\begin{array}{l}\text { Unit weight }(\mathrm{g} / \\
\left.\mathrm{cm}^{3}\right)\end{array}$ & $\begin{array}{c}\text { Initial weight, } \\
M_{1}(\mathrm{~g})\end{array}$ & $\begin{array}{c}\text { Dry weight, } \\
M_{2}(\mathrm{~g})\end{array}$ & $\begin{array}{l}\text { Water absorption by weight, } \\
W_{a}(\%)\end{array}$ & $\begin{array}{c}\text { TS } 2824 \text { EN } 1338 \text { specification } \\
\text { limit }(\%)\end{array}$ \\
\hline RWC & 2.149 & 4880 & 4604 & 5.9 & \multirow{6}{*}{$W_{a} \leq 6$} \\
\hline RCC & 2.027 & 4880 & 4604 & 5.9 & \\
\hline ASWC & 2.046 & 4647 & 4401 & 5.6 & \\
\hline ASCC & 1.938 & 4647 & 4401 & 5.6 & \\
\hline MSWC & 2.185 & 4963 & 4741 & 4.7 & \\
\hline MSCC & 2.088 & 4963 & 4741 & 4.7 & \\
\hline
\end{tabular}

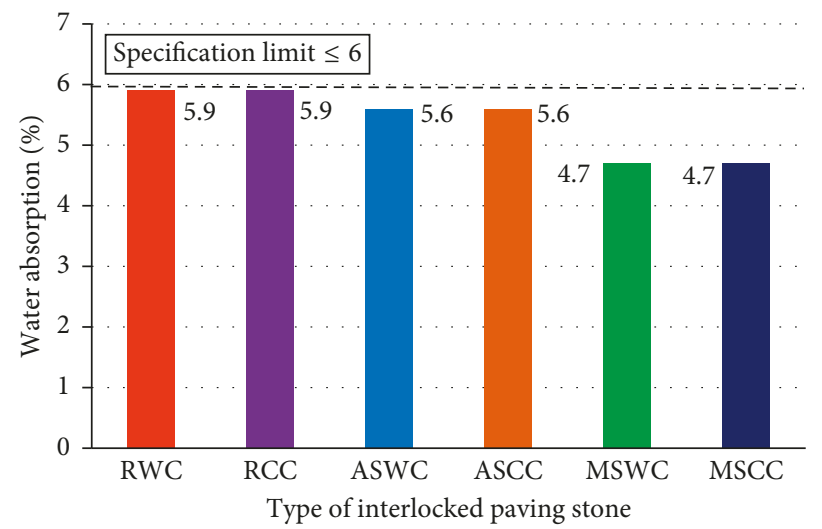

Figure 7: Results of the absorption test for each type of interlocked paving stones. 


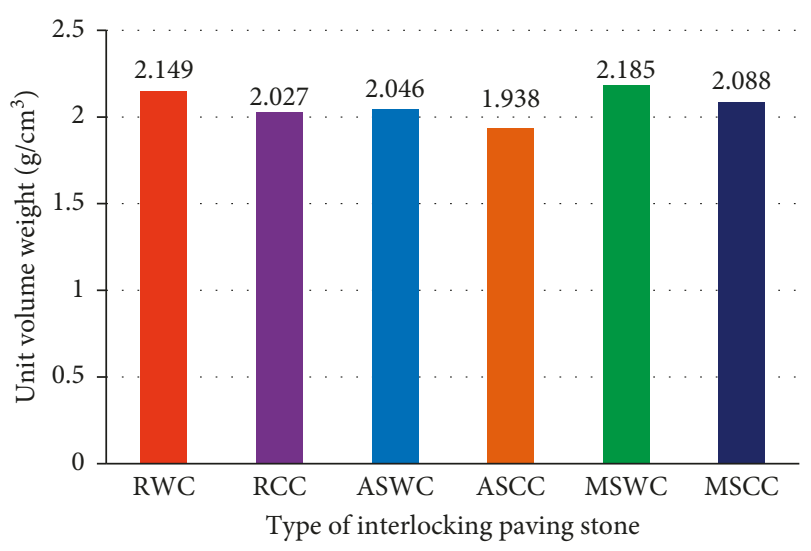

FIGURE 8: Unit volume weight of the locked paving stones.

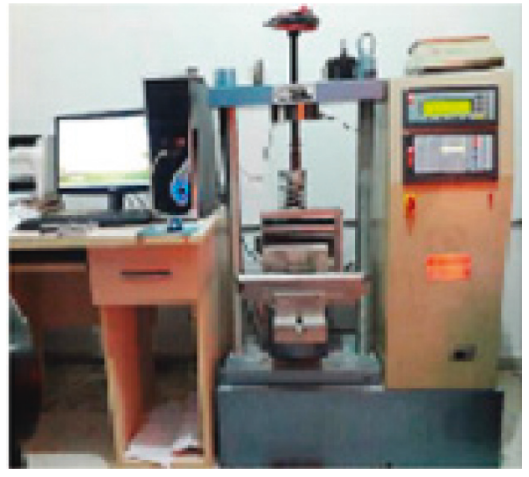

(a)

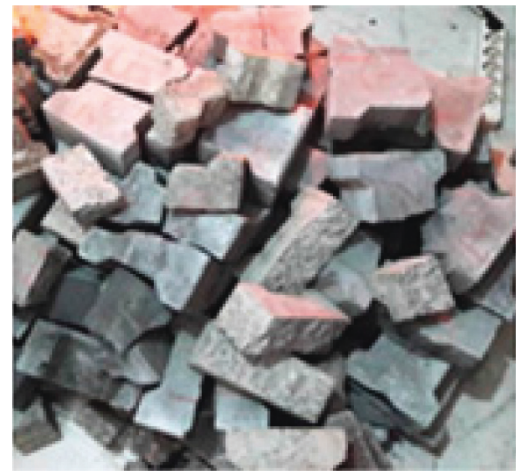

(b)

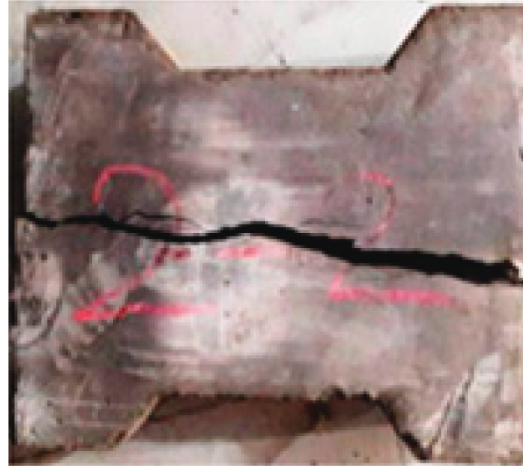

(c)

FIgURE 9: Specimen samples for the splitting tensile strength test. (a) Test device. (b) Broken samples. (c) Length of breakage.

TABLE 18: Results of the splitting tensile strength test.

\begin{tabular}{lccc}
$\begin{array}{l}\text { Interlocked paving stone } \\
\text { type }\end{array}$ & $\begin{array}{c}\text { Splitting tensile strength, } T_{\text {(average) }} \\
(\mathrm{MPa})\end{array}$ & $\begin{array}{c}\text { Splitting load per unit area, } F_{\text {(average) }} \\
(\mathrm{N} / \mathrm{mm})\end{array}$ & $\begin{array}{c}T_{\text {(average) }}(\mathrm{MPa}) \\
F_{(\text {average) }}(\mathrm{N} / \\
\mathrm{mm})\end{array}$ \\
\hline RWC (reference) & 3.6 & 444 & \\
RCC & 3.8 & 466 & $T_{\text {(average) }}$ \\
ASWC & 3.7 & 460 & $F_{(\text {average }} \geq 250$ \\
ASCC & 3.9 & 479 & $\mathrm{~N} / \mathrm{mm}$ \\
MSWC & 3.9 & 488 & 510 \\
MSCC & 4.1 & 510 & \\
\hline
\end{tabular}

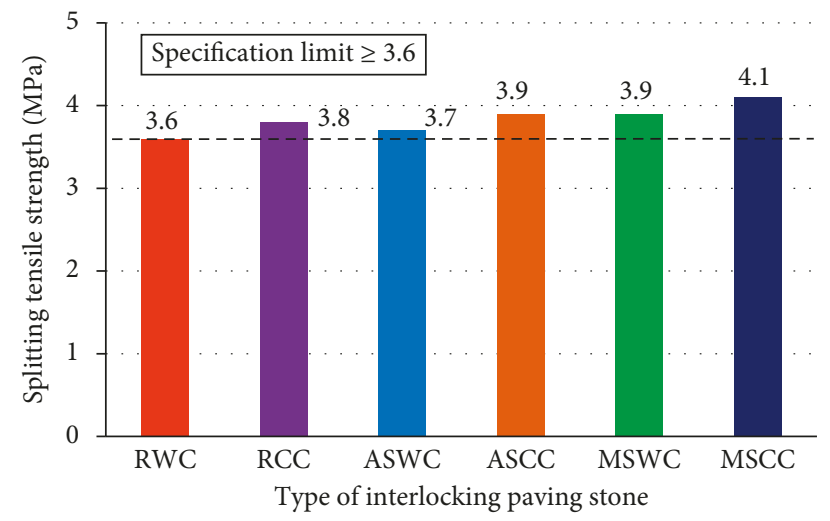

FIGURE 10: Results of the splitting tensile strength test for the interlocked paving stones. 

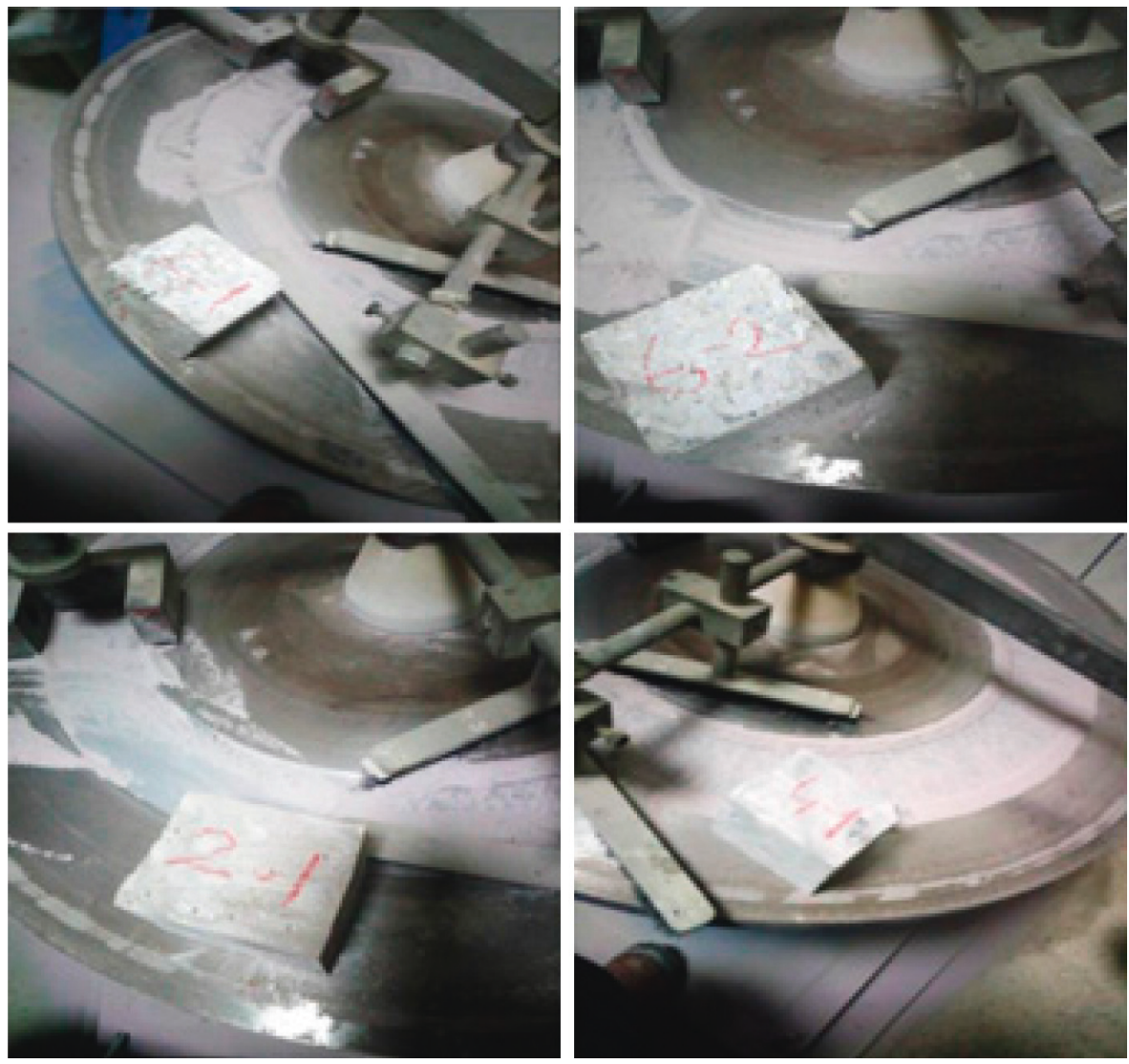

Figure 11: Abrasion test for RWC, RCC, ASWC, and MSWC interlocked paving stones.

TABLE 19: Results of the abrasion test for the interlocked paving stones.

\begin{tabular}{lcccc}
\hline $\begin{array}{l}\text { Interlocked paving stone } \\
\text { type }\end{array}$ & $\begin{array}{c}\text { Density } \rho r(\mathrm{~g} / \\
\left.\mathrm{cm}^{3}\right)\end{array}$ & $\begin{array}{c}\text { Mass loss } \Delta m \\
(\mathrm{~g})\end{array}$ & $\begin{array}{c}\text { Abrasion } \Delta V\left(\mathrm{~cm}^{3} /\right. \\
\left.50 \mathrm{~cm}^{2}\right)\end{array}$ & $\begin{array}{c}\text { TS 2824 EN 1338 specification limit }\left(\mathrm{cm}^{3} /\right. \\
\left.50 \mathrm{~cm}^{2}\right)\end{array}$ \\
\hline RWC (reference) & 1.989 & 18.4 & 9.2 & \\
RCC & 1.956 & 19.7 & 10.0 & $\Delta V \leq 18$ \\
ASWC & 1.986 & 19.5 & 9.8 & 17.2 \\
ASCC & 1.985 & 34.2 & 7.9 & \\
MSWC & 1.993 & 15.8 & 14.8 & \\
MSCC & 1.991 & 29.5 &
\end{tabular}

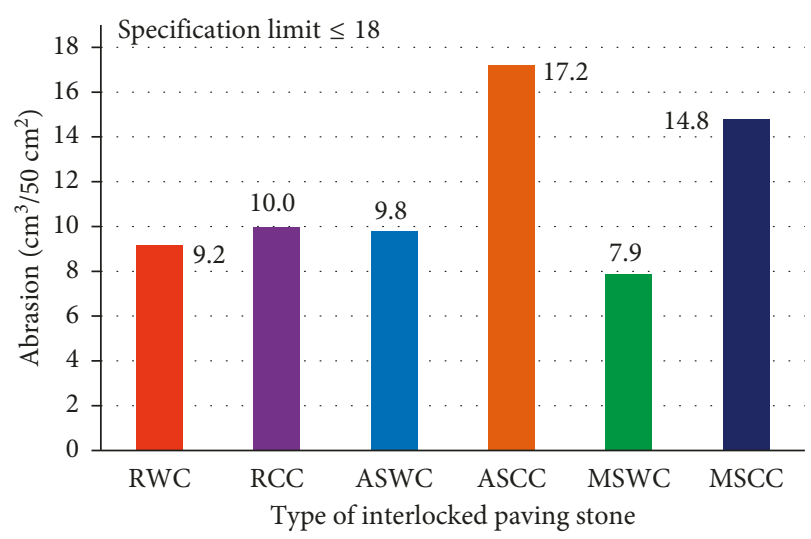

FIGURE 12: Results of the abrasion test for the interlocked paving stones. approximately 3\%. The freeze-thaw mass loss of RCC, ASCC, and MSCC was higher, respectively, than that of RWC, ASWC, and MSWC.

Figure 13 describes the results of the freeze-thaw test. Such a high temperature $\left(200^{\circ} \mathrm{C}\right)$ induces other durability issues, such as delayed ettringite formation, since ettringite is not formed during the hydration process. Therefore, freezethaw values of RCC, ASCC, and MSCC were higher, respectively, than that of RWC, ASWC, and MSWC. From Table 20 and Figure 13, the values of mass loss per unit area (I) for all paving stones defined a specification limit. Results of all the tests performed for the interlocked paving stones are summarized in Table 21.

As such, all five new types of interlocked paving stones, namely, RCC, ASWC, ASCC, MSWC, and MSCC, defined the specification limits of test results. 
TABLE 20: Results of the freeze-thaw test results of interlocked paving stones.

\begin{tabular}{|c|c|c|c|c|}
\hline Interlocked paving stone type & Surface area, $A\left(\mathrm{~mm}^{2}\right)$ & $\begin{array}{c}\text { Mass loss, } \\
M(\mathrm{~g})\end{array}$ & $\begin{array}{l}\text { Mass loss per unit area, } I \\
\left(\mathrm{~kg} / \mathrm{m}^{2}\right)\end{array}$ & TS 2824 EN 1338 specification limit $\left(\mathrm{kg} / \mathrm{m}^{2}\right)$ \\
\hline RWC (reference) & 9600 & 3.36 & 0.35 & \multirow{6}{*}{$I \leq 1$} \\
\hline $\mathrm{RCC}$ & 9600 & 4.61 & 0.48 & \\
\hline ASWC & 9600 & 3.74 & 0.39 & \\
\hline ASCC & 9600 & 6.05 & 0.63 & \\
\hline MSWC & 9600 & 3.26 & 0.34 & \\
\hline MSCC & 9600 & 5.47 & 0.57 & \\
\hline
\end{tabular}

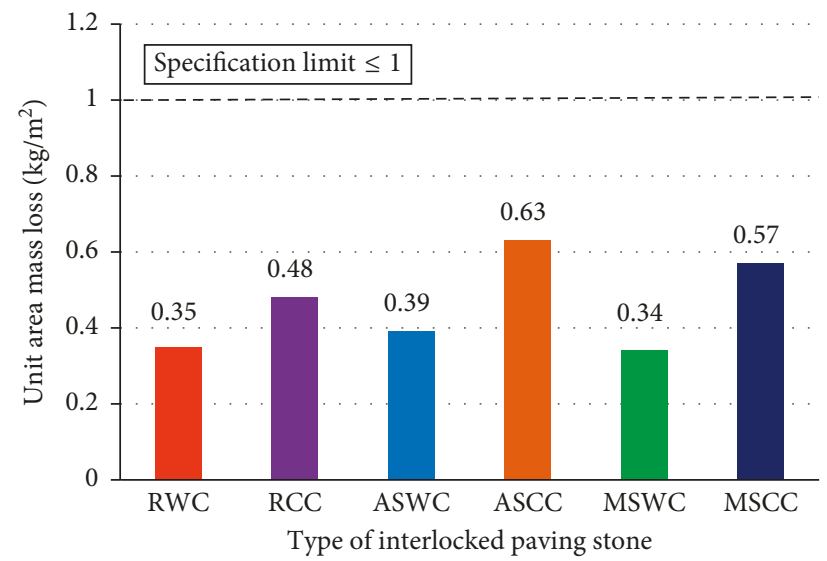

FIGURE 13: Results of the freeze-thaw test for the interlocked paving stones.

TABLE 21: All test results of interlocked paving stones.

\begin{tabular}{lcccccccc}
\hline Tests & RWC & RCC & ASWC & ASCC & MSWC & MSCC & $\begin{array}{c}\text { TS 2824 EN 1338 specification } \\
\text { limit }\end{array}$ & $\begin{array}{c}\text { Standard deviation } \\
(\sigma)\end{array}$ \\
\hline Unit volume weight $\left(\mathrm{g} / \mathrm{cm}^{3}\right)$ & 2.149 & 2.027 & 2.046 & 1.938 & 2.185 & 2.088 & Unspecified & $\leq .09$ \\
Water absorption $(\%)$ & 5.9 & 5.9 & 5.6 & 5.6 & 4.7 & 4.7 & $\leq 6.0$ & 0.56 \\
Splitting tensile strength & 3.6 & 3.8 & 3.7 & 3.9 & 3.9 & 4.1 & $\geq 3.6$ & 0.18 \\
$(\mathrm{MPa})$ & 9.2 & 10 & 9.8 & 17.2 & 7.9 & 14.8 & $\leq 18$ & 3.65 \\
Abrasion $\left(\mathrm{cm}^{3} / 50 \mathrm{~cm}^{2}\right)$ & 0.35 & 0.48 & 0.39 & 0.63 & 0.34 & 0.57 & $\leq 1.0$ & 0.12 \\
Freeze-thaw $\left(\mathrm{kg} / \mathrm{m}^{2}\right)$ & & & & & & &
\end{tabular}

\section{Conclusions}

The usability of waste materials Ahlat stone powder and marble powder in fabricating interlocked paving stones was the focal subject of investigation for this study. As there was no study in the provided literature that considered the production of interlocked concrete paving stones with Ahlat stone powder, such was realized with Ahlat stone powder of size range $0.15-0.60 \mathrm{~mm}$. Since the porosity of the Ahlat stone is high, it cannot be used as coarse aggregate in the concrete mixture. With the special curing method, durable concrete paving stones are produced from waste Ahlat stone powders. Likewise, a few studies considered marble aggregate in the production of interlocked paving stones, and none of these employed marble powder in $100 \%$ ratio of the aggregates, which was realized herein, with marble powder specimens of size range $0.15-0.60 \mathrm{~mm}$. Six different types of interlocked paving stones were fabricated under two curing types, one of which was a reference concrete. Tests of water absorption, splitting tensile strength, surface abrasion, and freeze-thaw for each interlocked paving stone type were carried out. Test results for the five new types of concrete were compared with the reference-interlocked paving stone concrete under specification limits. The findings of this study can be generalized as follows:

(i) Waste materials, i.e., ignimbrite (Ahlat stone) powder and marble powder for this study, can be used in the production of interlocked paving stones.

(ii) Combined curing increases the splitting tensile strength of interlocked paving stones at $5 \%$, on average.

(iii) New types of interlocked paving stones were produced from the cited waste materials. Of these, ASCC is the lightest (in particular, it was approximately $10 \%$ lighter than the reference-interlocked paving stone (RWC)); MSCC achieved the highest splitting tensile strength, and MSWC had the lowest abrasion loss. 
(iv) The abrasion loss of interlocked paving stones subjected to combined curing was higher than those applied with standard water curing, which indicates the progressing damage on the surface over time under high temperatures.

(v) MSWC had the lowest freeze-thaw mass loss, which indicates its higher resistance to damage than the other types under long-time, adverse climatic conditions.

(vi) Subsequent scientific studies may extend delayed ettringite formation and fatigue and impact tests for the new types of interlocked paving stones fabricated in this study.

(vii) Delayed ettringite formation for the new types of interlocked paving stones can be investigated in subsequent scientific studies.

\section{Data Availability}

The data used to support the findings of this study are included within the article.

\section{Conflicts of Interest}

The author declares that there are no conflicts of interest regarding the publication of this paper.

\section{Acknowledgments}

The author would like to thank Bitlis Eren University Rector and its staff, ADABAG Building Incorporated Company, ULTRA Building Materials and Quality Control Concrete Laboratory Industry and Trade Limited Company, and VAN LAKE Building Quality Control Laboratory Construction Industry Trade Limited Company, for their significant contributions in the realization of this study. They would also like to extend their appreciation to ENAGO for the English language review.

\section{References}

[1] M. Semiz, "Research of the physical characteristics of concrete keystone and alternative production," Master thesis, Gazi University, Graduate School of Natural and Applied Sciences, Ankara, Turkey, 2006.

[2] Y. Acikgoz, "Research in usage of fly ashes in the production of interlocking concrete pave," Master thesis, Gazi University, Graduate School of Natural and Applied Sciences, Ankara, Turkey, 2008.

[3] T. Kaya and C. Karakurt, "Investigation of the engineering properties of implementation concrete paving stones," Duzce University Journal of Science and Technology, vol. 4, no. 2, pp. 469-474, 2016.

[4] T. Tekmen, "Evaluate to mechanical properties of concrete interlocking pavement blocks which was produced from limestones," Master thesis, Cukurova University, Graduate School of Natural and Applied Sciences, Adana, Turkey, 2006.

[5] MEGEP, Covering in Sidewalk and Parks, Construction Technology, Ankara, Turkey, 2012.
[6] B. I. Topcu and T. Uygunoglu, "Use of marble aggregate and fly ash in the production of interlocked paving stones," Concrete Prefabrication, vol. 98, pp. 15-16, 2011.

[7] G. Yang and M. A. Bradford, "Thermal-induced upheaval buckling of continuously-reinforced semi-infinite concrete pavements," Engineering Structures, vol. 168, pp. 865-876, 2018.

[8] G. Yang and M. A. Bradford, "Thermal-induced upheaval buckling of concrete pavements incorporating the effects of temperature gradient," Engineering Structures, vol. 164, pp. 316-324, 2018.

[9] A. Bakis, "Usability of ahlat stone in rigid pavement construction,” BEU Journal of Science, vol. 5, no. 2, pp. 164-171, 2016.

[10] F. Hattatoglu and A. Bakis, "Usability of ignimbrite powder in reactive powder concrete road pavement," Road Materials and Pavement Design, vol. 18, no. 6, pp. 1448-1459, 2017.

[11] M. Bostanci, "Investigation of capillary water absorption behaviour of ignimbrites (Nevsehir Region)," Master thesis, Nevsehir Haci Bektas Veli University, Graduate School of Natural and Applied Sciences, Nevsehir, Turkey, 2016.

[12] B. I. Topcu and T. Uygunoglu, Reduction of Environmental Pollution by Using Waste Marble Aggregates in Concrete, International Sustainable Structures Symposium, Ankara, Turkey, 2010.

[13] M. Filiz, C. Ozel, O. Soykan, and Y. Ekiz, "Usage of waste marble dust at paving stones," Electronic Journal of Construction Technologies, vol. 6, no. 2, pp. 57-72, 2010.

[14] H. Ceylan and S. Manca, "Evaluation of concrete aggregate marble pieces," SDU Journal of Technical Sciences, vol. 3, no. 2, pp. 21-25, 2013.

[15] L. G. Li, Z. H. Huang, Y. P. Tan, A. K. H. Kwan, and H. Y. Chen, "Recycling of marble dust as paste replacement for improving strength, microstructure and eco-friendliness of mortar," Journal of Cleaner Production, vol. 210, pp. 55-65, 2019.

[16] K. Vardhan, R. Siddique, and S. Goyal, "Strength, permeation and micro-structural characteristics of concrete incorporating waste marble," Construction and Building Materials, vol. 203, pp. 45-55, 2019.

[17] R. Alyousef, O. Benjeddou, C. Soussi, M. A. Khadimallah, and M. Jedidi, "Experimental study of new insulation lightweight concrete block floor based on perlite aggregate, natural sand, and sand obtained from marble waste," Advances in Materials Science and Engineering, vol. 2019, Article ID 8160461, 14 pages, 2019.

[18] E. T. Tunc, "Recycling of marble waste: a review based on strength of concrete Containing marble waste," Journal of Environmental Management, vol. 231, pp. 86-97, 2019.

[19] D. K. Ashish, "Concrete made with waste marble powder and supplementary cementitious material for sustainable development," Journal of Cleaner Production, vol. 211, pp. 716-729, 2019.

[20] M. Pathirage, F. Bousikhane, M. D’Ambrosia, M. Alnaggar, and G. Cusatis, "Effect of alkali silica reaction on the mechanical properties of aging mortar bars: experiments and numerical modeling," International Journal of Damage Mechanics, vol. 28, no. 2, pp. 291-322, 2018.

[21] TS 2824 EN 1338, Concrete Paving Blocks-Requirements and Test Methods, TSE, Ankara, Turkey, 2005.

[22] TS EN 197-1, Cement - Part 1: Composition, Specifications and Conformity Criteria for Common Cements, TSE, Ankara, Turkey, 2012. 
[23] ASTM C618-19, Standard Specification for Coal Fly Ash and Raw or Calcined Natural Pozzolan for Use in Concrete, ASTM International, West Conshohocken, PA, USA, 2019.

[24] AASHTO M 307, Standard Specification for Silica Fume Used in Cementitious Mixtures, American Association of State Highway and Transportation Officials, Washington, DC, USA, 2013.

[25] Limak Cement Industry and Trade Inc, http://www. limakcement.com.

[26] BASF Chemistry Industry and Trade Inc, http://www.masterbuilders-solutions.basf.com.tr.

[27] TS EN-934-2+A1, Admixtures for Concrete, Mortar and Grout-Part 2: Concrete Admixtures-Definitions, Requirements, Conformity, Marking and Labelling, TSE, Ankara, Turkey, 2014.

[28] Adabag Building Industry Incorporated Company, http:// www.adabag.com.tr.

[29] O. Simsek and M. Erdal, "Investigation of some mechanical and physical properties of the Ahlat stone (Ignimbrite)," Gazi University Journal of Science, vol. 17, no. 4, pp. 71-78, 2004.

[30] HMF Marble Industry, http://www.hmfmarble.com.tr.

[31] Z. Gezen, "Grain size influences on the material properties and durability of marbles," Master thesis, Dokuz Eylul University, Graduate School of Natural and Applied Sciences, Izmir, Turkey, 2013.

[32] TS EN 933-1, Tests for Geometrical Properties of Aggregates-Part 1: Determination of Particle Size Distribution-Sieving Method, TSE, Ankara, Turkey, 2012.

[33] TS 802, Design of Concrete Mixes, TSE, Ankara, Turkey, 2016.

[34] M. Ipek, "Effects of pre-setting pressure applied during setting phase to mechanical behaviors of reactive powder concrete," $\mathrm{Ph}$ D. thesis, Sakarya University, Graduate School of Natural and Applied Sciences, Sakarya, Turkey, 2009.

[35] A. Bakis, "Investigation on the usability of reactive powder concrete (rpc) in rigid road superstructure construction," $\mathrm{Ph}$ D. thesis, Ataturk University, Graduate School of Natural and Applied Sciences, Erzurum, Turkey, 2015.

[36] F. Larrard and T. Sedran, "Optimization of ultra-high-performance concrete by the use of a packing model," Cement and Concrete Research, vol. 24, no. 6, pp. 997-1009, 1994.

[37] P. Richard and M. Cheyrezy, "Composition of reactive powder concretes," Cement and Concrete Research, vol. 25, no. 7, pp. 1501-1511, 1995. 


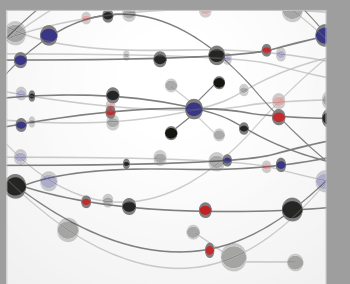

The Scientific World Journal
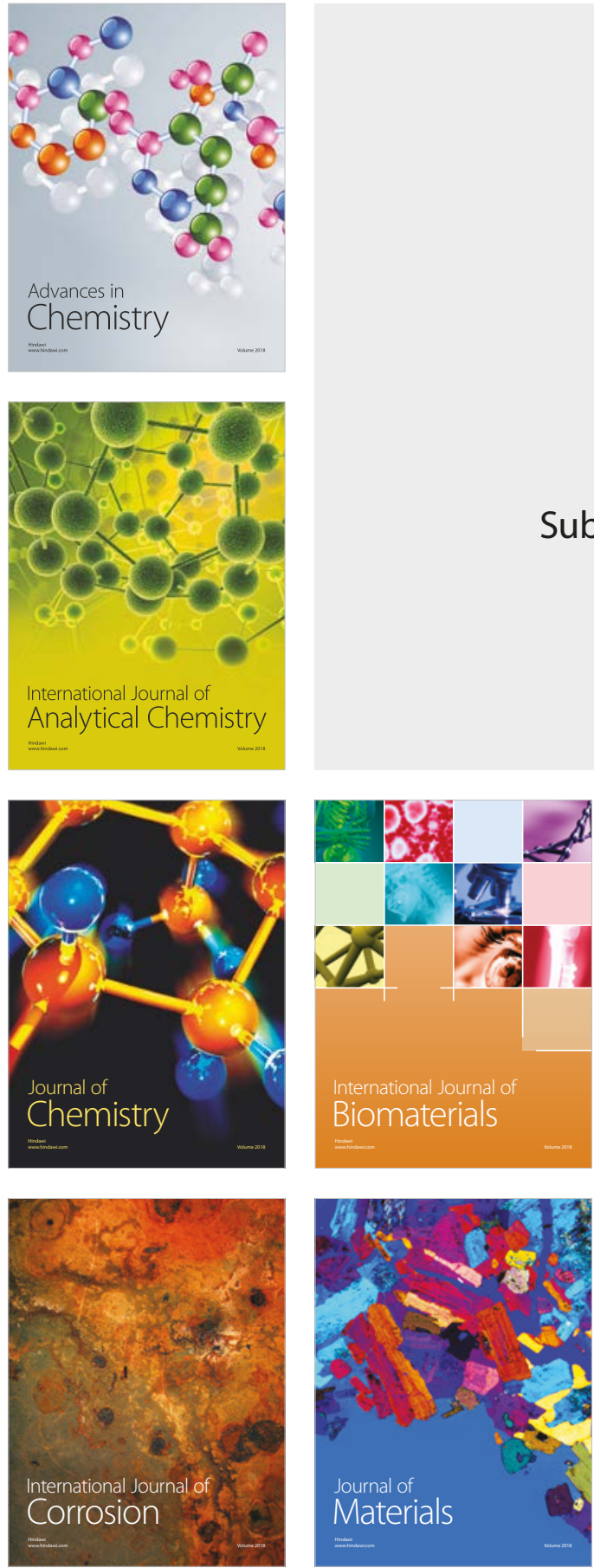

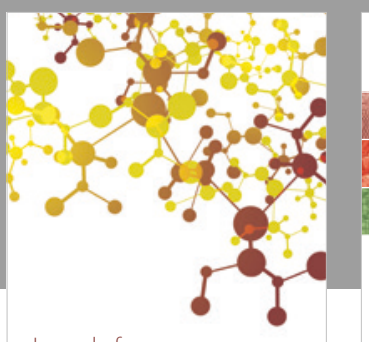

Journal of

Applied Chemistry
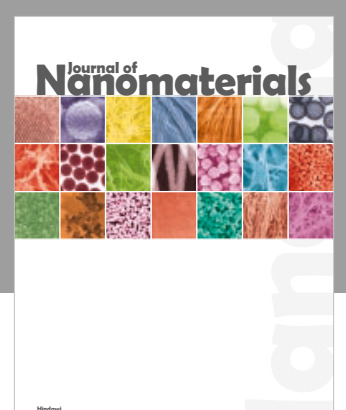

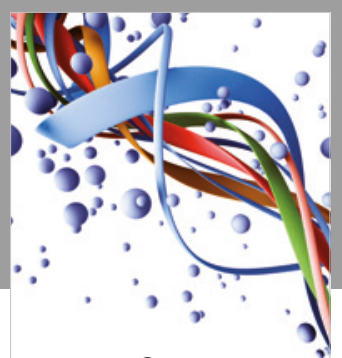

Scientifica

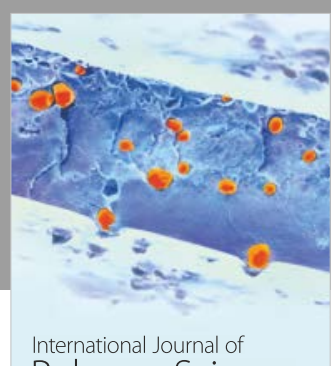

Polymer Science

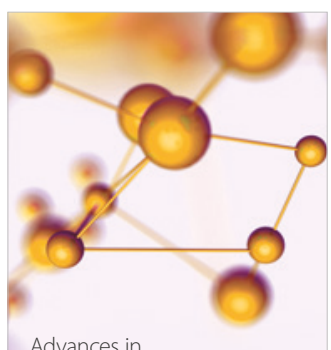

Physical Chemistry
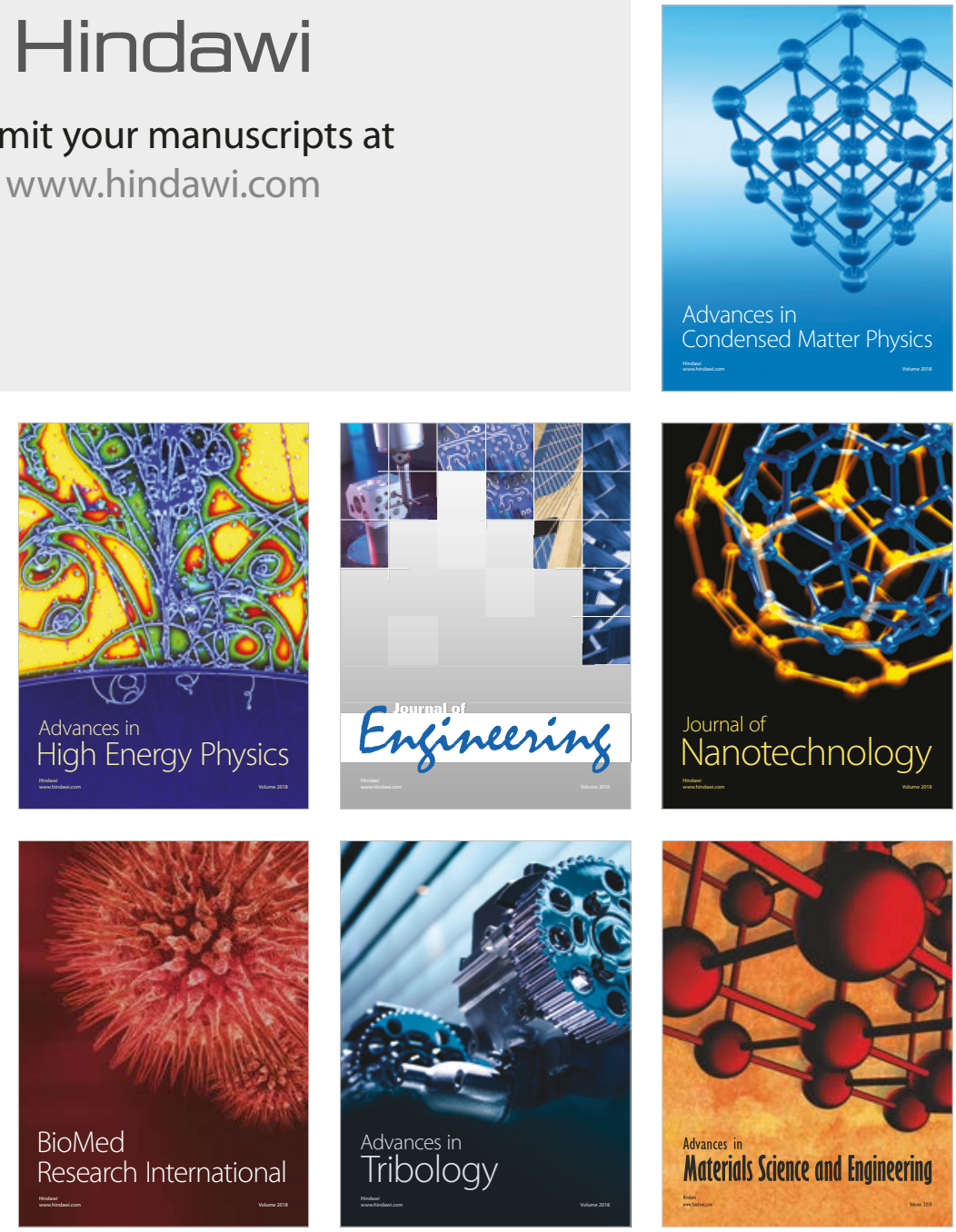